\title{
THE RELATIONSHIP OF STAFF JOB SATISFACTION AND INTENTION TO LEAVE FROM A HOSPITAL
}

\author{
Hubungan Kepuasan Kerja Pegawai dan Keinginan untuk Keluar dari Rumah Sakit
}

\author{
Diajeng Puspa Arum Maharani ${ }^{1}$, ${ }^{*}$ Nimas Ayu Mashuri² \\ ${ }^{1}$ Persakmi Surabaya, Indonesia \\ ${ }^{2}$ Faculty of Public Health, Universitas Airlangga, Indonesia \\ *Correspondence: nimas.ayu.mashuri-2015@fkm.unair.ac.id
}

\begin{abstract}
Background: Job dissatisfaction arises as a result of a mismatch between expectation and reality in the employment conditions of employees in an organization. Job dissatisfaction can lead to the intention of to leave. Employees with Intention to leave have the opportunity to do turnover of their organization.

Aims: The purpose of this study is to determine the relationship between job satisfaction variable and intention to leave variable.

Methods: This study used quantitative method with cross-sectional design. The samples were 52 staffs of the Surabaya Orthopaedic and Traumatology Hospital who were still actively working until June 2012. Job satisfaction variable was measured using a questionnaire research instrument called Job Satisfaction Survey (JSS) by Spector while the intention to leave variable was measured using a questionnaire research instrument that is made by researchers.

Results: The results of this study indicate that the level of staff work satisfaction of Surabaya Orthopaedic and Traumatology Hospital is relatively high while the intention to leave is moderate. The results of the Spearman Correlation show a number of -0.314 which shows a correlation that is not unidirectional and significant between the two variables. This means that job satisfaction and intention to leave have a negative relationship so that the higher the job satisfaction is, the lower the intention to leave is.

Conclusion: It can be concluded from the study that job satisfaction has a significant relationship and is not in line with the intention to leave of the staffs. Therefore, it is important for the Surabaya Orthopaedic and Traumatology Hospital to improve their staff job satisfaction thus the staff loyalty can be formed.
\end{abstract}

Keywords: Job satisfaction, Intention to leave, Hospital staff.

\begin{abstract}
ABSTRAK
Latar Belakang: Ketidakpuasan kerja timbul sebagai akibat dari ketidaksesuaian harapan dan kenyataan pada kondisi pekerjaan pegawai di organisasi. Ketidakpuasan kerja tersebut dapat memunculkan keinginan untuk keluar dari dalam diri pegawai. Pada pegawai dengan Keinginan untuk keluar memiliki peluang untuk melakukan turnover terhadap organisasi.

Tujuan: Tujuan dari penelitian ini adalah untuk mengetahui hubungan variable kepuasan kerja terhadap variable keinginan untuk keluar.

Metode: Penelitian ini menggunakan metode kuantitatif dengan desain cross-sectional. Sampel penelitian berjumlah 52 orang yang berasal dari total pegawai RS Orthopedi dan Traumatology Surabaya yang masih aktif bekerja hingga Juni 2012. Variabel kepuasan kerja diukur menggunakan instrument penelitian kuesioner yaitu Job Satisfaction Survey (JSS) oleh Spector, sedangkan variable keinginan untuk keluar diukur menggunakan instrument penelitian kuesioner yang dibuat oleh peneliti.

Hasil: Hasil penelitian ini menunjukkan tingkat kepuasan kerja pegawai RS Orthopedi dan Traumatologi Surabaya tergolong tinggi dengan tingkat keinginan untuk keluar sedang. Hasil Correlation Spearman menunjukkan angka sebesar -0,314 yang menunjukkan adanya korelasi signifikan dan tidak searah terhadap dua variable tersebut. Hal ini berarti bahwa kepuasan kerja dan keinginan untuk keluar memiliki hubungan negatif sehingga semakin tinggi kepuasan kerja maka semakin rendah keinginan untuk keluar yang ada pada diri pegawai.

Kesimpulan: Kesimpulan dari penelitian ini adalah kepuasan kerja memiliki hubungan yang signifikan dan tidak searah terhadap keinginan untuk keluar pegawai. Oleh karena itu penting bagi RS Orthopedi dan Traumatology Surabaya untuk berupaya meningkatkan kepuasan kerja pegawai agar terbentuk loyalitas pada pegawai.
\end{abstract}

Kata Kunci: Kepuasan kerja, Keinginan untuk keluar, Pegawai rumah sakit.

Received: 3 November 2018 Accepted: 30 January 2019 Published: 29 April 2019

\section{INTRODUCTION}

Human resource is one of the vital assets in an organization since organizational success is mostly determined by the element of human (Ardana, Mujiati and Utama, 2012). Every organization has a goal that must be achieved, and one of the parties that carry out the role is 
employees. According to Mangkuprawira (2007), employees have material and non-material needs that must be valued by their organization. The material needs can be in the form of compensation and career received while the non-material needs can be in the form of respect for the staffs as members of the social system of the organization. If these needs are met, the staffs will be satisfied and organizational goals can be carried out effectively and efficiently. This is why the organization is required to provide guarantees for the staff job satisfaction.

Job satisfaction is a general attitude of an individual towards his work (Robbin and Timothy, 2008). Job satisfaction is a general attitude towards someone's work that shows the difference between the number of awards received and the number of awards he should receive. A person with a high level of job satisfaction will hold positive feelings towards his work. On the other hand, someone with a low level of job satisfaction will show negative attitudes towards his job. In general, when talking about staff's attitudes, it will refer to the staff's job satisfaction (Robbins \& Coulter 2012).

Staff's job satisfaction also has an impact on organizational productivity (Sari, Armanu and Afnan, 2016). According to Putra (2017), when an individual works in an organization, the results of the work completed will affect the level of organizational productivity. Therefore, these individuals must maintain their job satisfaction to improve their productivity. The statement is in accordance with the research of Harrisma and Witjaksono (2013), stating that job satisfaction has a positive and significant effect on work productivity.

Job satisfaction is influenced by many factors. According to Nasution, Musnadi and Faisal (2018), work involvement, workload and organizational culture have a significant and positive effect on staff job satisfaction. In the end, job satisfaction brings positive and significant effect on staff performance (Nasution, Musnadi and Faisal, 2018). The discrepancy of staffs' expectations and reality of the working conditions in the organization can lead to job dissatisfaction.

Employees with high stress of work can also experience job dissatisfaction (Damar, Yasa, and Sitiari, 2017). Job dissatisfaction can trigger the staffs' desire to quit the work, or commonly called, intention to leave. This is in accordance to the result of Putra's research (2017) which states that job satisfaction has a positive effect on intention to leave. In addition, employees who have high commitment to the organization may change the other employees' intention to move out or leave the organization (Ayu, 2016). Job satisfaction is also able to increase the employee motivation to work, so the probability to be consistent with work goals is even greater (Indy and Handoyo, 2013). The existence of work motivation can also improve employee work performance (Putra and Wikansari, 2017).

The staffs with intention to leave may execute turnover in their organization. Turnover is a permanent dismissal of a staff from the company which may be done either by the staff himself, or by the company (Robbins and Timothy, 2008).
Turnover occurs because of three factors i.e. company factors, personal factors, and external environmental factors. The company factors include company size, policy, job characteristics, job security, organizational culture, organizational learning culture, job involvement, perceived organizational support and psychological atmosphere. While personal factors affecting turnover can be in the form of age, gender, education, skill, interest, behavioural control, health, marital status, family size, work period, workload, work commitment, job satisfaction and intention to leave. Lastly, the external environmental factors include hospital location, hospital competitors, job availability and employment opportunities outside the profession.

One of the personal factors that cause turnover is the intention to leave of the staff. The turnover process is basically initiated by a staff's desire to quit the organization, or simply called, intention to leave. Intention to leave is the staff's motive to get out of the organization deliberately (Ayu, 2016). Berry \& Morris (2008) argued that intention to leave refers to the voluntary intention of an employee to leave the organization. This is evidenced by the emergence of the intention to leave before the employee actually leaves the organization.

An employee with the intention to leave has great possibility to do turnover. The intention to leave is marked by a variety of things related to the staff's behavior, such as increased attendance, laziness to work, and increased courage to oppose superiors. According to Harnoto (2002), each sign can be used as a reference to predict the intention to leave of employees in an organization.

Intention to leave can occur through a psychological process (Mangkuprawira, 2007). Initially, an employee feels a decline in the level of job satisfaction. Soon after, low job satisfaction will decrease motivation which is characterized by the emegence of stress, physical illness, laziness to work, decreasing work quality, diminishing personal communication and ignorance towards his work tasks. The employee will start to contemplate about finding alternative employment. The employee will compare the alternative job with his current job and make decision to stay or to leave the company. The last stage is the action decided by the employee to stay or leave the organization.

According to Mathis and Jackson (2009), there are several components determining the intention to leave, whether a staff stay or leave the organization, namely organizational components, staff relations, career opportunities, awards and design of tasks and jobs. Meanwhile, according to Mobley (1986), the factors that determine the intention to leave are organizational factors, individual factors, external factors and internal factors. Organizational factors include job category, size of the organization, size of the work unit, salary and workload. On the other hand, individual factors cover age, work period, gender, education, geographic data, personality, interest and talent. Internal factors include organizational culture, leadership style, job satisfaction, compensation and career development. For the last, external factors 
consist of environmental and individual aspects. From the theory explanation, it can be seen that satisfaction influences staff's intention to leave. An employee who has the intention to leave the organization will likely to execute turnover.

Every organization needs to know and understand the causes of turnover since turnover induces costs for the organization (Putra, 2017). Those costs consist of promotion costs, recruitment fees and staff coaching costs. When an organization experience a turnover, the organization has lost some staffs and should replace them with new ones to keep the organization running. This can lead to an adverse impact to the organization (Putra, 2017).

Turnover does not only cause loss by the emersion of the costs, but also brings other damages to the organization. These damages may include production loss during the staff turnover, accidents caused by the inexperienced new staffs, not optimal use of production equipment, and overtime work that has to be done by the staffs who still remain in the organization to avoid production delays. Therefore, a high turnover rate in an organization needs to be handled seriously since it can threaten the survival of the organization.

Surabaya Orthopaedic and Traumatology Hospital were established in 2010. Health services provided by the hospital are in the form of specialization and subspecialty in the field of traumatology and Orthopaedic that is supported by radiology specialists, Medical Rehabilitation, and Medical and Surgical Support. According to the Law of Ministry of Health of Republic of Indonesia Number 44 of 2009, hospital is a health service institution that performs individual health services completely by providing inpatient, outpatient, and emergency services. In providing a complete health service, the hospital is required to have qualified human resources. Therefore, the hospital is required to manage its human resources very well since they play an important role in the success of hospital services and has become one of the factors that shows the competitive advantage of the hospital (Ayu, 2016).

However, Surabaya Orthopaedic and Traumatology Hospital still has some constraints regarding its human resource assets or staffs in its operation. In the period from January to June of 2012 , the employee turnover rate is $26,92 \%$ or increasing reached $1,39 \%$ from the previous period. It is caused by changing number of employee by addition of 28 staffs and reduction of 14 staffs. It means that the number of the staffs who left the hospital was half of the number of the staffs recruited. The study conducted by Ayu (2016) shows that the level of Staff turnover of the Surabaya Orthopaedic and Traumatology Hospital in 2012 reached $88 \%$. According to these data, it can be concluded that the turnover rate of Surabaya Orthopaedic and Traumatology Hospital staffs in 2012 was high and the hospital staffs intention to leave was quite high. Turnover in health care organizations is a serious challenge to the efficiency and effectiveness of every health care system since it brings negative impact.

Using previous study result descriptions as bases, this study aims to examine the relationship of job satisfaction and intention to leave of the Surabaya Orthopaedic and Traumatology Hospital staffs. Researchers choose to study the intention to leave due to the fact that there is high intention to leave of Orthopaedic and Traumatology Hospital staffs. Besides, the employee turnover rate in the first semester of 2012 was $26.92 \%$ while the total employee turnover rate in 2012 was $88 \%$. Job satisfaction is studied since staff job satisfaction is the fundamental factor that affect intention to leave and hospital productivity. This research uses quantitative study approach so that in-depth interviews are not conducted to present in-depth information about a relationship or phenomenon. This has become a limitation for the study and will be written as a suggestion for the future researchers.

\section{METHOD}

This study used quantitative methods with cross-sectional research. This research was conducted at the Surabaya Orthopaedic and Traumatology Hospital. The population of this study is all staffs of the Surabaya Orthopaedic and Traumatology Hospital who were still actively working. The sampling technique used was 52 staffs at the Surabaya Orthopaedic and Traumatology Hospital who still actively worked until June 2012, were chosen as the samples of this study. The independent variable in this study was job satisfaction while the dependent variable was the intention to leave. Data analysis techniques used were descriptive statistical analysis and correlation.

Secondary data were generated from the general description of Surabaya Traumatology and Orthopaedic Hospital containing brief history, vision, mission, goals, and organizational structure of the Surabaya Orthopaedic and Traumatology Hospital. Primary data were collected using questionnaire research instrument. The job satisfaction variable was measured by the JSS questionnaire that is adopted from Spector (1997). Meanwhile, the intention to leave variable was measured by a questionnaire that is made by the researcher and have been proved for its validity and reliability. Before filling out the questionnaires, respondents were asked to sign informed consent attached. Data collection was conducted for two weeks. Questionnaires were distributed to the respondents by adjusting to the respondents' shift schedule. The questionnaire results were in the form of interval data and grouped into four categories, namely low, medium, high, and very high. Data grouping was done by dividing the difference of minimum score and maximum score with four to determine the score interval in each category. Finally, each variable was analyzed using Spearman correlation to determine the relationship of each research variable.

\section{RESULTS AND DISCUSSION}

\section{The Characteristics of Respondents by Gender and Work Unit}

Respondents in this study are staffs of Surabaya Orthopaedic and Traumatology Hospital 
who were still actively working until June 2012 amounting to 52 people. The majority of the respondents is female. There are 35 female staffs $(67.31 \%)$ and 17 male staffs (32.69\%). According to Robbin and Timothy (2008), gender can affect employee turnover and lesser turnover is done by male staffs. Yet, it does not rule out the possibility of male staffs to do more turnovers due to the number of family members borne or any other factors. Female staffs have higher commitment since they believe that the responsibility of their household is in their husbands. This is why the salary provided by the organization is not something vital to them.

Table 1. Work Unit of the Respondents.

\begin{tabular}{lcc}
\hline Work Unit & Frequency & Percent \\
\hline Human Resources & 3 & 5.77 \\
\hline House Keeping & 5 & 9.62 \\
\hline $\begin{array}{l}\text { Central Surgical } \\
\text { Installation or } \\
\text { Instalasi Bedah } \\
\text { Sentral (IBS) }\end{array}$ & 3 & 5.77 \\
\hline $\begin{array}{l}\text { Medical Facility } \\
\text { Maintenance } \\
\text { Installation }\end{array}$ & 1 & 1.92 \\
\hline $\begin{array}{l}\text { Non-Medical } \\
\text { Facility }\end{array}$ & & \\
$\begin{array}{l}\text { Maintenance } \\
\text { Installation }\end{array}$ & 3 & 5.77 \\
\hline Financial & & \\
\hline Pharmacy & 4 & 7.69 \\
\hline Laboratory & 4 & 7.69 \\
\hline General & 4 & 7.69 \\
\hline Outpatient & 3 & 5.77 \\
\hline Inpatient & 6 & 11.54 \\
\hline Front Office & 6 & 11.54 \\
\hline Radiology & 3 & 5.77 \\
\hline $\begin{array}{l}\text { Medical } \\
\text { Administration }\end{array}$ & 3 & 5.77 \\
\hline Physiotherapist & 1 & 1.92 \\
\hline Medical record & 52 & 3.85 \\
\hline Total & & 1.92 \\
\hline & & \\
\hline & 3 & \\
\hline
\end{tabular}

Respondents were taken from 16 hospital work units namely: Human Resources Unit, Housekeeping Unit, Central Surgical Installation Unit, Medical Facility Maintenance Installation Unit, Non-Medical Facility Maintenance Installation Unit, Financial Unit, Pharmacy Unit, Laboratory Unit, General Unit, Outpatient Unit, Inpatient Unit, Front Office Unit, Radiology Unit, Medical Administration Unit, Physiotherapist Unit and Medical Record Unit. The details of the number of respondents per unit are as follows are illustrated in Table 1.

According to table 1 above, it is known that most of the respondents come from inpatient and outpatient work units amounting to 6 people each. The number is followed by the 5 respondents who come from the household work unit. The smallest numbers of respondents come from the Medical Facility Maintenance Installation unit, the Medical Administration Unit, and the Medical Record unit with 1 person each. Work units are indirectly related to employee turnover through other factors, namely group integration, personality, and communication (Mujiati and Dewi, 2016).

\section{Job Satisfaction of Surabaya Orthopaedic and Traumatology Hospital Employees}

In the job satisfaction variable, out of 52 respondents, 41 people or $78.85 \%$ of Surabaya Orthopaedic and Traumatology Hospital staffs have a high level of job satisfaction. Whereas, $19.23 \%$ or as many as 10 staffs have a very high level of job satisfaction and $1.92 \%$ or only 1 staff has a low level of job satisfaction. Thus, it can be concluded that the staff job satisfaction at Traumatology and Orthopaedic Hospital is high.

Robbin and Timothy (2008) suggested that job satisfaction is a form of positive response by a staff to a job based on the characteristics evaluation results. Spector (2016) defined job satisfaction as an attitude that describes a staff's response to a work as a whole various aspects of the work. Based on the results of the research by Nurandini and Lataruva (2014), high job satisfaction will support high performance. While high performance will bring success to the organizational process.

There are nine aspects studied in the job satisfaction questionnaire used for this study, namely award, promotion, supervision, work benefit, reward, operational procedure, co-worker, nature of work, and communication. The aspect that brings the highest level of staff satisfaction of Surabaya Orthopaedic and Traumatology Hospital is the nature of work. It is then followed by aspects of supervision, co-worker, award, reward, promotion, work benefit, and communication. Lastly, the aspect with lowest satisfaction level is operating procedure.

The best aspect to bring job satisfaction is the nature of the work. This result is in line with the study conducted by Kardilla, Sjahruddin and Heslina (2016), stating that employment characteristics are aspects that have a significant effect on employee job satisfaction. This shows that the employee has comfort in his work and the workload he receives is in accordance with his ability to work in the Orthopaedic and Traumatology Hospital in Surabaya. Thus, the staffs feel no difficulty working in the Surabaya Orthopaedic and Traumatology Hospital. This is related to the staff recruitment and training processes.

The type of work given to an employee affects the staff job satisfaction. The employee will feel satisfied if the work charged is quite diverse and interesting for him. According to Herzberg's twofactor theory, interesting and challenging work is a factor that employees need to become a source of job satisfaction beside having the opportunity to excel and receive promotions or awards.

At the same time, the procedure operation brings the lowest job satisfaction to the Surabaya Orthopaedic and Traumatology Hospital. The procedure operation is the regulatory policy applied 
by the hospital. The staffs have difficulties in carrying out their work and the difficulty is related to the work procedures that have been applied by the hospital. Operating procedures may prevent staffs from doing their work effectively and efficiently. Therefore, the hospital needs to provide solutions regarding operating procedures that can harm the process and results of the staffs' work otherwise the staffs will feel dissatisfied with their work.

\section{Intention to Leave of Surabaya Orthopaedic and Traumatology Hospital Employees}

Before a turnover occurs, a staff develops a motive to quit his work called intention to leave (Ayu, 2016). Out of 52 respondents, 20 people or $38.46 \%$ of the staffs have high intention to leave. As much as $55.76 \%$ of staffs, or 29 people, have medium level of intention to leave while $5.77 \%$, or 3 staffs, have low level of intention to leave.

Intention to leave indicates the possibility of an individual to change his work within a certain period. Based on the results of the study, the level of intention to leave in Surabaya Orthopaedic and Traumatology Hospital was classified as medium. Even so, the level of intention to leave needs to be corrected since it can increase staff turnover which in this study is considerately high. Intention to leave is the positive dominant predictor for the occurrence of turnover. Turnover, based on (Mobley, 1986), is the cessation of an individual as a member of an organization accompanied by the provision of financial rewards by the organization concerned.

According to Mobley et, al (1986), various factors may cause an employee to move out of his work, yet the determinant factors of the desire to leave are job satisfaction and staffs organizational commitment. The satisfactions related to the individual's intention to leave the organization are satisfaction of wages and promotions, satisfaction of supervision received, satisfaction of co-workers, and satisfaction of work and content of work. In this study, the intention to leave questionnaire has five aspects, namely work comparison, motive to leave, active search for another job, quit the company and resign for rewards. The staffs of Surabaya Orthopaedic and Traumatology Hospital give highest score regarding intention to leave variable on the quit the company aspect and the lowest score on the active search for another job aspect.

The high score of quit the company aspect shows that many staffs took the initiative to leave the company even though it was convenient to work in the Surabaya Orthopaedic and Traumatology Hospital. Based on the research conducted by Ayu (2016), staffs whose have the intention to leave will start to think about finding alternative jobs, compare those jobs, evaluate them, and finally make decision to survive or leave the organization. This is in accordance with three main indicators disclosing the intention to leave by Scott (2014), namely the desire to leave the workplace, the search of new jobs in different fields, and the evaluation of desire to leave the current workplace. According to Mardiana, Hubeis and Panjaitan (2014), the turnover intention indicators with relatively high point are resignation thinking indicator and job information searching indicator.

Quitting the company shows employee loyalty to the organization where he works (Spector, 1997). Staff loyalty to the organization is influenced by organizational commitment. Organizational commitment is an attitude that reflects employee loyalty to the organization and ongoing process of organizational members to focus on the organization as well as the success and progress of the organization (Nurandini \& Lataruva 2014). Job satisfaction and organizational commitment are interrelated variables (Sari, Armanu and Afnan, 2016). This is consistent with a study by llahi, Mukzam and Prasetya (2017which argues that job satisfaction has a positive and significant effect on organizational commitment. Therefore, high organizational commitment will result in positive employee attitudes and behaviors, such as loyalty to leader, high productivity, and performance.

\section{The Relationship between Job Satisfaction and Intention to leave of Surabaya Orthopaedic and Traumatology Hospital Employees}

From the results of crosstabulation, it is known that most staffs with high job satisfaction have medium intention to leave. Moderate level of intention to leave shows that the staffs of Surabaya Orthopaedic and Traumatology Hospital have a desire to do turnover and have a high chance to quit the job even though they are comfortable working in the hospital. The level of intention to leave can be increased by the employees' dissatisfaction toward their work.

According to Mobley (1986), the factors determining intention to leave are organizational factors, individual factors, external factors, and internal factors. So, besides being caused by job satisfaction, intention to leave can also be caused by environmental factors or personal factors of staffs. However, the results of this study indicate that the level of staff job satisfaction is high. It can be concluded that the intention to leave is at the medium level as a result of factors that are not related to the staff's work, namely environmental factors and personal factors.

Surabaya Orthopaedic and Traumatology Hospital can intervene intention to leave using factors related to hospital environment such as by increasing work facilities, adjusting works with policies, promoting the hospital and making adjustment regarding benefits provided compared to competitor hospitals. However, the other parties cannot control the personal factors of staff, such as age, education, interests, family, health and others. Thus, it is not right for Surabaya Orthopaedic and Traumatology Hospital to intervene these factors since they are the right of the staff. 
Table 2. Crosstabulation of Job Satisfaction with Intention to Leave in Surabaya Orthopaedic and Traumatology Hospital.

\begin{tabular}{llcccc}
\hline & & & Intention to Leave & Total \\
\cline { 2 - 5 } & & High & Medium & Low \\
\hline \multirow{2}{*}{ Job } & Very high & 1 & 8 & 1 & 10 \\
\cline { 2 - 5 } & High & 18 & 21 & 2 & 41 \\
\cline { 2 - 5 } & Medium & 1 & 0 & 0 & 3 \\
\hline Total & & 20 & 29 & 32 \\
\hline
\end{tabular}

According to Mathis and Jackson (2008), job satisfaction and intention to leave have a fairly strong and not unidirectional correlation. Table 3 illustrated the relationship analysis results of staff job satisfaction and intention to leave in Orthopaedic and Traumatology Hospital Surabaya. The statement is also in accordance with the results of Srinadi \& Supartha research (2015), which conclude that job satisfaction brings negative impact on intention to leave. This means the higher the staff job satisfaction, the lower the intention to leave.

The relationship of job satisfaction and intention to leave was tested with Spearman correlation. The variable correlation result shows that there is a relationship between the job satisfaction variable and the intention to leave variable with correlation coefficient of -0.314 which indicates that the correlation is significant and not inherent. This means that job satisfaction and intention to leave have a strong relationship and the higher the staff's job satisfaction, the lower the intention to leave of the staff.

The results of this study are in accordance with Mobley (1986), model which argues that job satisfaction aspect is related to the individual's desire to leave the organization. Another previous research which is in line with the finding of this study is conducted by Widodo (2010), that states that staff commitment from job satisfaction will have a small impact on staff's turnover intention. The results of this study are also supported by previous research conducted by Hidayat (2018), which conclude that job satisfaction and organizational commitment have a negative influence on intention to leave. It means that the higher the job satisfaction and organizational commitment of employees, the lower the desire of employee to leave.

The results also show that the staffs of Surabaya Orthopaedic and Traumatology Hospital are comfortable enough to stay in the hospital and have a high job satisfaction. Thus, it is advised for the hospital to increase its staff's job satisfaction to form staff loyalty. Loyalty is the obedience or loyalty that employees have for their company (Alfiyah, 2016). Loyalty can affect employee performance and is formed from staff's job satisfaction (Mathis and Jackson, 2008). Job satisfaction can be increased by accepting staff's aspirations for organizational improvement. Discrepancy theory states that satisfaction can be achieved if there is no difference between what should be there (hope, needs, values) and what has been obtained and achieved through work according to someone's feeling or perception. Therefore, capturing aspirations for organizational improvement, such as improvements to facilities, can support the staff's performance by reducing staff's workload. This in turn will increase staff's job satisfaction and bring an impact on staff loyalty.

Table 3. Relationship of Job Satisfaction with Intention to Leave in Surabaya Orthopaedic and Traumatology Hospital Employee.

\begin{tabular}{llc}
\hline \multicolumn{2}{c}{ Intention to Leave } \\
\hline \multirow{3}{*}{ Job Satisfaction Correlation } & $-.314^{*}$ \\
\cline { 2 - 3 } & Soefficient & .023 \\
\cline { 2 - 3 } Sig. (2-tailed) & 52 \\
\hline . Correlation is significant at the 0.05 level (2-tailed).
\end{tabular}

The findings of this study are contrary to a research conducted by Nur (2015), on the staffs of PT. Batuwangi Putera Sejahtera which shows no significant effect on intention to leave. The research of Nur (2015), is also supported by Zulfinur (2002), who argues that job satisfaction is not a factor causing a turnover. According to Robbins and Timothy (2008), this is because job satisfaction is not only influenced by job satisfaction, but also by other factors such as work period, labor market conditions, and alternative employment opportunities.

The findings in this study indicate that Surabaya Orthopaedic and Traumatology Hospital employees have the will to stay in the hospital due to their high job satisfaction. Thudd, it can be concluded that job satisfaction is related to the intention to leave of Surabaya Orthopaedic and Traumatology Hospital employees. The intention to leave must be eliminated by increasing staff job satisfaction since it may affect employee turnover.

Hospitals with high level of employee turnover can bring uncomfortable environment for employees to carry out their activities at work (Ayu, 2016). Staff resignation causes the hospitals to loose their experts and productivity (Sari, Armanu and Afnan, 2016). On the other hand, hospitals with low productivity may experience decreasing number of customers due to the low quality of services produced. The customers will come to the organizations with high work productivity and good quality service (Darmawan, 2013).

The Efforts to improve the job satisfaction can be done by providing the support and opportunities to the staffs to attend the training and seminars in which aim to improve skills, reward the staffs who have good performance, improve the work facilities, match the work with the policies, the hospital promotions and adjustment of benefits that are provided compared to competing hospitals. The Hospitals also need to develop the policies that support the hospital work operations and work procedures. Selection of aspirations for the staffs is needed to support and evaluate the situation in the 
hospital. These efforts can create a good organizational climate. In the end, good organizational climate will increase employee job satisfaction (Damar, Yasa, and Sitiari, 2017).

\section{CONCLUSION}

The results of this study shows that the level of staff job satisfaction of Surabaya Orthopaedic and Traumatology Hospital is high while the intention to leave level is moderate. From the results of the correlation test, it can be concluded that there is a significant and not unidirectional relationship between job satisfaction and staff's intention to leave. Higher job satisfaction will reduce the staff's intention to leave level in the Surabaya Orthopaedic and Traumatology Hospital. Therefore, it is important for the Surabaya Orthopaedic and Traumatology Hospital to improve their staff's job satisfaction, so loyalty of the staffs can be formed. Loyalty to the organization will decrease the staff's level of intention to leave. Thus, the high job satisfaction will decrease both the intention to leave rate and staff turnover. Finally, the job satisfaction will also increase the hospital productivity.

Efforts to increase job satisfaction can be made in the form of providing support and chance for the staffs to attend trainings and seminars with the aim of improving skills, providing rewards to staffs who have good performance, increasing work facilities, matching work with the policies, promoting the hospital and adjusting the benefits provided by the hospital compared with competing hospitals. The hospital also needs to develop policies that able to support the hospital activities and employment procedures. In addition, the staff's aspiration screening is needed to support and evaluate the hospital situation. The results of this study can be used as a base data for future researchers, especially the researches that relates to the relationship of the job satisfaction and the intention to leave. For the future researchers, they can use the interview method to deepen the phenomenon regarding the job satisfaction and intention to leave.

\section{CONFLICT OF INTEREST}

The authors declare that they have no conflict of interests.

\section{REFERENCES}

Alfiyah, S. E. (2016) 'Motivasi kerja, loyalitas, dan kualitas karyawan terhadap kinerja karyawan PT. Varia Usaha Gresik', BISMA, 8(2), pp. 144-155. doi: 10.26740/bisma.v8n2.p144155.

Alsaqri, S. H. (2014) A Survey of Intention to Leave, Job Stress, Burnout and Job Satisfaction among Nurses Employed in the Ha'il Region's Hospitals in Saudi Arabia. Doctorate Thesis. RMIT University.

Ardana, I. K., Mujiati, N. W. and Utama, I. W. M. (2012) Manajemen Sumber Daya Manusia. Yogyakarta: Graha IImu.

Ayu, D. P. (2016) Pengaruh Person-Environment Fit, Kepuasan Kerja dan Komitmen
Organisasional Terhadap Intention to Leave Pegawai (Studi di RS Orthopedi dan Traumatologi Surabaya). Master Thesis. Airlangga University.

Berry, M. L. and Morris, M. L. (2008) 'The Impact of Employee Engagement Factors and Job Satisfaction On Turnover Intent', in Academy of Human Resource Development International Research Conference in The Americas. Panama: ERIC.

Damar, I. G. N. P. A., Yasa, P. N. S. and Sitiari, N. W. (2017) 'Pengaruh Stres Kerja Dan Iklim Organisasi Terhadap Intention To Leave Dengan Kepuasan Kerja Sebagai Variabel Mediasi (Studi Pada Dinas Perindustrian Dan Perdagangan Provinsi Bali)', JAGADHITA, 4(2), pp. 1-13. doi: 10.22225/jj.4.2.202.1-13.

Darmawan, D. (2013) Prinsip-Prinsip Perilaku Organisasi. Surabaya: Pena Semesta.

H., H. I. and Handoyo, S. (2013) 'Hubungan Kepuasan Kerja Dengan Motivasi Kerja Pada Karyawan Bank BTPN Madiun', Jurnal Psikologi Industri dan Organisasi, 2(2), pp. 100-104.

Harnoto (2002) Manajemen Sumber Daya Manusia. 2nd edn. Jakarta: PT. Prenhallindo.

Harrisma, O. W. and Witjaksono, A. D. (2013) 'Pengaruh Stres Kerja Terhadap Produktivitas Kerja Melalui Kepuasan Kerja', Jurnal IImu Manajemen, 1(2), pp. 650-662.

Herzberg, F. (1959) The Motivation to Work. United States of America: Wiley \& Sons.

Hidayat, A. S. (2018) 'Pengaruh Kepuasan Kerja Terhadap Komitmen Organisasi Dan Turnover Intention', Jurnal Manajemen dan Pemasaran Jasa, 11(1), pp. 51-66. Available at: 10.25105/jmpj.v10i1.2516.

Ilahi, D. K., Mukzam, M. D. and Prasetya, A. (2017) 'Pengaruh Kepuasan Kerja Terhadap Disiplin Kerja Dan Komitmen Organisasional (Studi Pada Karyawan Pt.PLN (Persero) Distribusi Jawa Timur Area Malang)', Jurnal Administrasi Bisnis (JAB), 44(1), pp. 31-39.

Kardilla, T., Sjahruddin, H. and Heslina (2016) 'Dampak Karakteristik Pekerjaan dan Individu Pada Kepuasan Kerja Karyawan', ELibrary STIE YPBUP Bongaya, 2, pp. 49-63.

Mangkuprawira, S. and Hubeis, A. V. (2007) Manajemen Mutu Sumber Daya Manusia. Bogor: Ghalia Indoneisa.

Mardiana, I., Hubeis, A. V. S. and Panjaitan, N. K. (2014) 'Hubungan Kepuasan Kerja dengan Turnover Intentions pada Perawat Rumah Sakit Dhuafa', Manajemen IKM, 9(2), pp. 119-130. doi: 10.29244/119-130.

Mathis, R. L. and Jackson, J. H. (2009) Manajemen Sumber Daya Manusia. 10th edn. Jakarta: Salemba Empat.

Ministry of Health of the Republic of Indonesia (2009) Undang-Undang Republik Indonesia Nomor 44 Tahun 2009 Tentang Rumah Sakit.

Mobley, W. H. (1986) Pergantian Karyawan: Sebab Akibat dan Pengendaliannya. Jakarta: Pustaka Binaman Pressindo.

Mujiati, N. W. and Dewi, A. A. S. K. (2016) 'FaktorFaktor Yang Menentukan Intensi Turnover 
Karyawan Dalam Organisasi', Jurnal Ilmiah Forum Manajemen, 14(2), pp. 56-63. Available at: https://ojs.stimihandayani.ac.id/index.php/FM /article/view/139/91.

Nasution, E. H., Musnadi, S. and Faisal (2018) 'Faktor-Faktor Yang Mempengaruhi Kepuasan Kerja Dan Dampaknya Terhadap Kinerja Pegawai Kanwil Direktorat Jenderal Kekayaan Negara Aceh', Jurnal Magister Managemen, 2(1), pp. 123-134.

Nur, H. A. (2015) Analisis Pengaruh Kepuasan Kerja Dan Komitmen Organisasional Terhadap Intention To Leave Karyawan Di PT.Batuwagi Putera Sejahtera. Undergraduate Thesis. Widyatama University.

Nurandini, A. and Lataruva, E. (2014) 'Analisis Pengaruh Komitmen Organisasi Terhadap Kinerja Karyawan (Studi Pada Pegawai Perum PERUMNAS Jakarta)', Jurnal Studi Manajemen \& Organisasi, 11(1), pp. 78-91. doi: 10.14710/jsmo.v11i1.13164.

Putra, M. F. R. (2017) 'Pengaruh Kepuasan Kerja Dan Komitmen Organisasi Terhadap Intention To Leave Di Rumah Sakit Pura Raharja Surabaya', Jurnal Administrasi Kesehatan Indonesia, 5(2), pp. 99-104. doi: 10.20473/jaki.v5i2.2017.99-104.

Putra, M. H. and Wikansari, R. (2017) 'Pengaruh Motivasi Terhadap Performansi Kerja Karyawan', Jurnal Aplikasi Manajemen, Ekonomi dan Bisnis, 1(2), pp. 65-78.

Robbin, S. P. and Timothy, A. J. (2008) Perilaku Organisasi. 16th edn. Jakarta: Salemba Empat.

Robbins, S. P. and Coulter, M. A. (2012) Management. New Jersey: Pearson Education.

Sari, R. R. N., Armanu and Afnan, E. (2016) 'Pengaruh Kepuasan Kerja dan Komitmen
Organisasional Terhadap Intention To Leave Pada Karyawan Produksi Mitra Produksi Sigaret (MPS) Ngoro-Jombang', Jurnal Unmer, 3(1), pp. 54-64.

Scott, W. R. (2014) Financial Accounting Theory. 7th edn. Canada: Pearson.

Spector, P. E. (1997) Job Satisfaction: Application, Assessment, Causes, and Consequences. California: Sage Publication.

Spector, P. E. (2016) Industrial and Organizational Psychology: Research and Practice. 7th edn. Hoboken, NJ: John Wiley \& Sons. doi: 10.1017/CBO9781107415324.004.

Srinadi, N. N. and Supartha, W. G. (2015) 'Peran Mediasi Kepuasan Kerja Pada Hubungan Motivasi Kerja Dengan Intention To Quit', EJurnal Ekonomi dan Bisnis Universitas Udayana, 4(3), pp. 197-219.

Sujati, Y. G. G. (2018) Kepuasan Kerja: Arti Penting, Faktor-Faktor yang Mempengaruhi, dan Implikasinya bagi Organisasi. Undergraduate Thesis. Sanata Dharma University.

Widodo, R. (2010) Analisis Pengaruh Keamanan Kerja Dan Komitmen Organisasional Terhadap Turnover Intention Serta Dampaknya Pada Kinerja Karyawan Outsourcing. Diponegoro University.

Yadi, H., Nurliza and Maswadi (2013) 'Analisis Faktor-faktor Yang Mempengaruhi Kepuasan Kerja Karyawan Tetap Pada PT . Riau Agrotama Plantation Kapuas Hulu Estate', Jurnal Sains Mahasiswa Pertanian, 2(3), pp. $1-17$.

Zulfinur (2002) Analisis turnover karyawan di PT. Oto. Undergraduate Thesis. University of Indonesia. 